\title{
The Expression of Cytoplasmic and Membrane Proteins in Dog Adipose-Derived Stem Cells on Different Passages During Cultivation in Vitro
}

\author{
Larysa Kladnytska ${ }^{1}$, Anatoliy Mazurkevych ${ }^{1}$, Natalia Bezdieniezhnykh ${ }^{2}$, \\ Oleg Melnyc ${ }^{1}$, Sergiy Velychko ${ }^{3}$, Mykola Malyuk ${ }^{1}$, Vasyl Danilov ${ }^{1}$, \\ Yuriy Kharkevych ${ }^{1}$ and Magdalena Gryzinska ${ }^{4 *}$ \\ ${ }^{1}$ Department of Physiology, Pathophysiology and Immunology of Animals, National \\ University of Life and Environmental Sciences of Ukraine, 03041 Kyiv, Ukraine \\ ${ }^{2}$ Department of Experimental Cell Systems, R.E. Kavetsky Institute of Experimental \\ Pathology, Oncology and Radiobiology, National Academy of Sciences of Ukraine, \\ 03022 Kyiv, Ukraine \\ ${ }^{3}$ Hospital of Veterinary Medicine, 03022 Kyiv, Ukraine \\ ${ }^{4}$ Institute of Biological Basis of Animal Production, University of Life Sciences in \\ Lublin, Poland
}

\section{A B S T R A C T}

The objective of the study was immunophenotypic analysis of mesenchymal stem cells from dog adipose tissue during in vitro cultivation. Materials and Methods: Mesenchymal stem cells were obtained from dog adipose tissue by explant method. The cells were cultured in $\mathrm{CO}_{2}$ incubator by standard procedure. Expression of cytoplasmic and membrane proteins on dog stem cells from fat tissue at the $\mathrm{IV}^{\text {th }}$ and $\mathrm{X}^{\text {th }}$ passages was examined by immunohistochemical method using monoclonal antibodies. Determination the index of proliferation dogs adipose-derived stem cells (DADSCs) on IV $V^{\text {th }}$ and $\mathrm{X}^{\text {th }}$ passages. Established that DADSCs contains multipotent stem cells, that are characterized by an almost homogenous fibroblastlike cells on the $\mathrm{IV}^{\text {th }}$ and $\mathrm{X}^{\text {th }}$ passages. It was difined, that fibroblast-like cells on the $\mathrm{IV}^{\text {th }}$ and $\mathrm{X}^{\text {th }}$ passages was expressed cytoplasmic and membrane proteins, which are specific to proliferating cells. Proliferation index in adipose-derived stem cells culture was significantly greater at the $\mathrm{IV}^{\text {th }}$ passage $-1.90 \pm 0.02$, compared to cells the $\mathrm{X}^{\text {th }}$ passage $-1,52 \pm 0,04 * *(\mathrm{P}<0.01)$. DADSCs at the $\mathrm{IV}^{\text {th }}$ passage are characterized by a maximum level of expression of pan cytokeratin $-299 \pm 0.6$, actin $-299 \pm 0,58$, vimentin $-265,7 \pm$ 20,7 , E-cadherin $-298,3 \pm 1$ points, indicating that this cells have a high adhesive properties, proliferation activity, cell signaling, interaction and mobility. The level of expression of these proteins remains high in the stem cells culture also at the $\mathrm{X}^{\text {th }}$ passage, although it is significantly lower in relation to the $\mathrm{IV}^{\text {th }}$ passage. At the $\mathrm{IV}^{\text {th }}$ passage adipose stem cells are characterized by average values of $\beta$-catenin expression $-97,7$ $\pm 8,5$ points, and low values of CD44 expression $-26,3 \pm 3,1$ points, which were significant decreased at the $\mathrm{X}^{\text {th }}$ passage of cultivation. The result of variance analysis revealed a significant effect of cell passaging on the level of expression of cytoplasmic and membrane proteins.

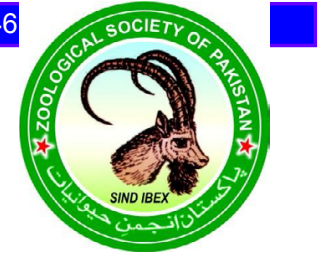

CrossMark

\begin{tabular}{l} 
Article Information \\
\hline Received 26 April 2017 \\
Revised 16 May 2018 \\
Accepted 14 September 2019 \\
Available online 17 April 2020 \\
Authors' Contribution \\
\hline AM and LK planned and executed \\
the project. LK, OM, VD, YK and \\
MG analyzed the results and wrote \\
the manuscript. NB, SV and MM \\
provided technical assistance. LK \\
supervised the whole project. \\
Key words \\
Mesenchymal stem cells, Adipose \\
tissue, Immunophenotypic analysis, \\
Cytoplasmic and membrane proteins, \\
Proliferation index
\end{tabular}

Received 26 April 2017

Revised 16 May 2018

Accepted 14 September 201

Authors' Contribution

A and LK planned and executed provided technical assistance. $\mathrm{LK}$ supervised the whole project.

esenchymal stem cells, Adipose

Cytoplasmic and membrane proteins, Proliferation index

\section{INTRODUCTION}

$\mathrm{O}$ btaining of biological material, in particular stem cells, for using in correcting of various pathological processes in the organism has gained relevance in veterinary medicine (Giordano et al., 2007; Lee et al., 2012; Kladnytska et al., 2014). In the stroma of adipose tissue was found a population of progenitor stem cells with multilinear differentiation potential similar to up.lublin.pl 0030-9923/2020/0004-1547 \$ 9.00/0

Copyright 2020 Zoological Society of Pakistan mesenchymal stem cells (MSCs) derived from bone marrow (Zuk et al., 2001). Considering that adipose tissue often can be obtained without traumatisation to the body, for example during operations like ovariohysteroectomy, as opposed to obtaining of bone marrow, it can be considered as an alternative source of MSCs, which can be used for transplantation. The results of the study of differentiation of stem cells allows to justify their use for therapeutic purposes and to confirm the clinical efficacy of new developments, based on stem cells properties, in the direction of veterinary medicine (Sasaki et al., 2008; Lee et al., 2012; Stefan and Wenisch, 2015). Characteristics of cell culture enables the evaluation of its biological properties (Andraszek et al., 2012, 2016; Chomik et al., 
2016; Azam et al., 2019; Jamali et al., 2019). Among modern research methods of identification of stem cell commonly are used method of immunohistochemical detection of marker proteins (Chamberlain et al., 2007; Bara et al., 2014). Number of marker proteins which are used in this, constantly growing, and is still not completely understood their functional role in the cell. N-cadherin has effects on adherens junction and regulates the proliferation and differentiation of cells (Chalasani and Brewster, 2011). The canonical Wnt/ $\beta$-catenin signaling pathway plays a crucial role in the maintenance of the balance between proliferation and differentiation throughout embryogenesis and tissue homeostasis. $\beta$-Catenin, encoded by the Ctnnb 1 gene, mediates an intracellular signaling cascade activated by Wnt. It also plays an important role in the maintenance of various types of stem cells including adult stem cells and cancer stem cells (Okumura et al., 2013; Zhang et al., 2014). In unstimulated cells with vimentin, most of the endogenous $\beta$-catenin is found in cell-cell contact joints, where it interacts with E-cadherin and $\beta$-catenin, providing interaction between neighboring cells (Yu et al., 2016). Vimentin - protein of intermediate filaments of the cytoskeleton, which is expressed by neural and glial cellspredecessors, as well as neurons, fibroblasts and smooth muscle cells. This protein is involved in the processes of cell adhesion, proliferation, migration and cell signaling (Zhang et al., 2014). CD44 take a part in fetal and adult hematopoetic stem cells regulation (Qian et al., 2012; Cao et al., 2016). E-cadherin maintains the activity of neural stem cells and inhibits the migration (Chen et al., 2015; Konze et al., 2014). E-cadherin and other cells adgesion molecules take a part in survival and differentiation of human pluripotent stem cells (Li et al., 2012).

The objective of the study was to perform an immunophenotypic analysis of mesenchymal stem cells from dog adipose tissue on different passages during in vitro cultivation.

\section{MATERIAL AND METHODS}

All researches on animals were carried out according to Guide for the Care and Use of Laboratory Animals (National Research Council, 1996). The experiment was approved by the Commission on Bioethics Institute of Veterinary Medicine NAAS of Ukraine, Resolution No. $1 / 2014$ for conduction of experiments on animals.

\section{Isolation of mesenchymal stem cells from dog adipose tissue}

Adipose tissue was obtained in sterile conditions from dogs under 1 year age during planned operations (ovariohysterectomy, suturing of hernia) under general anaesthesia. The dogs were sedated by intravenous injection with Sedazin ( $0.3 \mathrm{mg}$ of xylazine per $1 \mathrm{~kg}$ of b.w.). As a general anaesthetic Zoletil was administered intravenously at a dose of $10 \mathrm{mg} / \mathrm{kg}$ of b.w. Thus, every time were taken approximately $5 \mathrm{~g}$ of subcutaneous fat. Then adipose tissue was placed in a container filled with normal saline solution containing antibiotic and antimycotic agents, transferred to a transport container $\left(4^{\circ} \mathrm{C}\right)$, and transported to the laboratory. Further procedures were carried out in a sterile laminar cabinet. The adipose tissue were washed several times with PBS, released from the vessels, and cut into pieces of 2-3 $\mathrm{mm}$, which were plated in Petri dishes, covered with a blanket lenses for better contact with plastic and were cultivated (Bunnell et al., 2008; Neupane et al., 2008; Kladnytska et al., 2016).

\section{Cells cultivation}

The Petri dishes $(\mathrm{d}=35,60 \mathrm{~mm})$ with adipose tissue were cultured in $\mathrm{CO}_{2}$ incubator $\left(5 \% \mathrm{CO}_{2}\right.$ and $\left.37.0^{\circ} \mathrm{C}\right)$ by standard procedure. The culture media contained $80 \%$ of Dulbecco's modified Eagle'smedium and 20\% of foetal bovine serum with $10 \mu \mathrm{l} / \mathrm{mL}$ of antibiotic-antimycotic solution. The culture medium was replaced every $72 \mathrm{~h}$. When monolayer confluency reached about $80 \%-90 \%$, the cells were transferred to a suspension using $0.05 \%$ trypsin-EDTA solution and reseeded in a ratio of 1 to 3 . The cell suspension obtained was filtered through four layers of sterile gauze cloth, centrifuged, resuspended in culture media, and reseeded in Petri dishes in a ratio of 1 to 3 . The microscopic examination of cell culture quality and prolipheration was conducted every day with inverted microscope Axiovert 40 (Carl Zeiss, Germany) (Neupane et al., 2008; Kladnytska et al., 2016).

\section{Immunophenotypic analysis}

The cells of $\mathrm{IV}^{\text {th }}$ and $\mathrm{X}^{\text {th }}$ passages were seeded on cover glasses and grew for 48-72 h. After the monolayer reached about $50 \%-70 \%$ confluency, the cells were fixed in fixing solution (methanol + acetone, 1:1) for 2 $\mathrm{h}$ at $-20^{\circ} \mathrm{C}$, washed several times with PBS, incubated with a $1 \%$ solution of bovine serum albumin (BSA) for $20 \mathrm{~min}$, and treated with monoclonal antibodies against: E-cadherin - EP700Y (REF-R4-2100-SO), Vimentin SP 20 (REF-RM-9120-SO), Beta-Catenin (REF-RB-9035PO), Keratin, Pan Ab-1 (Clone AE1/AE3, REF-MS343-PO), Thermo-Scintific, USA, Mouse anti Actin Pan Anibody (REF-235-05), Diagnostic Biosystems, Purified anti-human CD $325 \mathrm{~N}$-cadherin (clone 8C11) Biolegend, USA, Mouse anti CD 44 (clone REF-Mob-256-05), Diagnostic Biosystems) for 30-60 $\mathrm{min}$ in accordance with theinstructions for monoclonal antibody application. For visualisation of reactions the Ultra Vision LPValue Detection system (Thermo Scientific), which contain 
detecting antibody, conjugated with peroxidase, was used. Enzyme activity was detected by using of diaminobenzidine (Thermo Scientific) as a substrate (Detre et al., 1995). After conducting an immunocytochemical reaction, the preparations werewashed with water and stained with Mayer haematoxylin (Sigma) for 1-2 min, and placed in Faramount Aqueous Mounting Medium (Gluzman et al., 2000). The results were analysed by counting the number of positively stained cells (brown staining) and evaluated by theclassical H-Score method: $\mathrm{S}=1 \mathrm{xA}+2 \mathrm{xB}+3 \mathrm{xC}$, where $\mathrm{S}-\mathrm{H}-\mathrm{Score}$ index. The values range from 0 (antigen not detected) to 300 (strong expression in 100\% of cells); A - percentage of weakly stained cells; B - percentage of moderately stained cells; $\mathrm{C}$ - percentage of strongly stained cells

\section{Determination of index of proliferation (IP)}

Dogs adipose-derived stem cells (DADSC) $\mathrm{IV}^{\text {th }}$ and $\mathrm{X}^{\text {th }}$ passages were plated at a density of $5 \times 10^{3}$ cells per square $\mathrm{cm}$ in Petri dish (diameter $=35 \mathrm{~mm}$ ). After 48 hours of incubation, the DADSCs were transferred to a suspension using $0.05 \%$ trypsin-EDTA solution, were washed with PBS and calculated in Goriaev's chamber. To calculate the proliferation index (IP) the number of calculated cells was divided on the number of cells, that were plated.

\section{Statistical analysis}

The results were statistically analysed by using Student's t-test for significance of differences between means. Differences at $\mathrm{P} \leq 0.05, \mathrm{P} \leq 0.01$, and $\mathrm{P} \leq 0.001$ were considered significant or highly significant. The tables show the mean and standard deviation. To determine the relationship of passaging to expression of protein markers correlation analysis was carried out (establish the likelihood of correlation coefficients). In all cases, the difference was considered reliable at $r \leq 0,05$. To establish the impact $\left(\eta^{2} x\right)$ of passage on the expression of marker proteins and likelihood of such effects a single-factor analysis of variance was carried out.

\section{RESULTS}

\section{Morphological features of DADSCS}

On day 6-7 after seeding, adherent cells left the explants, proliferated and created a round colonies with fibroblast-like cells, visible on several areas of culture surface. During 10-15 days after initial cell seeding (explant planting), cells reached about 80 percent of confluency and the culture consisted of an almost homogenous fibroblast-like cells. On the $\mathrm{IV}^{\text {th }}$ and $\mathrm{X}^{\text {th }}$ passages obtained homogenous cell population was used to conduction of immunophenotypic analysis (Fig. 1). Throughout the cultivation period, the cells maintained their fibroblastic morphology.
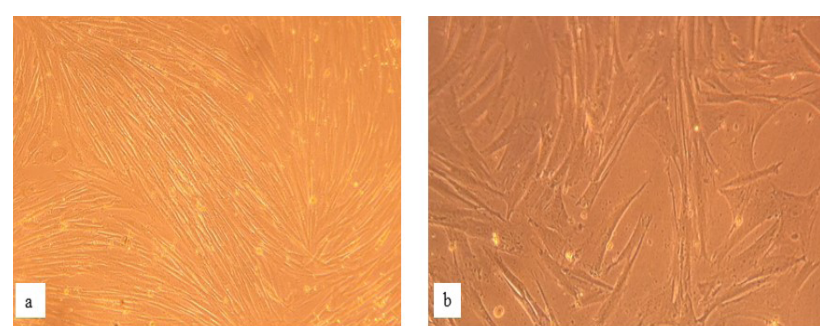

Fig. 1. Native unstained culture DADSCs: a) IV th passage, $100 \times$; b) $X^{\text {th }}$ passage, $\times 200$.

\section{Immunophenotypic characterisation of DADSCS}

Immunocytochemical analysis of the CD-receptor system of DADSCs at the $\mathrm{IV}^{\text {th }}$ and $\mathrm{X}^{\text {th }}$ passages indicates that the expression level of specific proteins significantly changes during cultivation (Table I). Vimentin is a typical marker of mesenchymal cells - it is a protein of intermediate filaments of the cytoskeleton of the cell. It was found a significant number of vimentin-positive cells with high expression of protein activity at the $\mathrm{IV}^{\text {th }}$ passage and significant reduction of its amount by $29 \%$ the $X^{\text {th }}$ passage. This change of the expression of vimentin shows, that with increasing number of passages gradually reduces the level of cell adhesion, proliferation, cell signaling and migration processes.

Table I. Immunophenotypic profile of dog adipose derived mesenchymal stem cells at the $I V^{\text {th }}$ and $X^{\text {th }}$ passages (mean \pm standard deviation, $n=3$ ).

\begin{tabular}{lll}
\hline Antigen & $\begin{array}{l}\text { Expression level of specific proteins, } \\
\text { assessment in points by the H-Score method } \\
\text { (from 0 to 300) }\end{array}$ \\
\cline { 2 - 3 } $\mathbf{I V}^{\text {th }}$ passage & $\mathbf{X}^{\text {th }}$ passage \\
\hline Vimentin & $265,7 \pm 20,7$ & $189 \pm 13,4^{*}$ \\
Actin & $299 \pm 0,58$ & $261,3 \pm 10,8^{*}$ \\
E-cadherin & $298,3 \pm 0,97$ & $223 \pm 15,68^{* *}$ \\
N-cadherin & 0 & 0 \\
CD44 & $26,3 \pm 3,1$ & $15,3 \pm 1,9^{*}$ \\
Pan cytokeratin & $299 \pm 0,6$ & $109 \pm 9,3^{* * *}$ \\
$\beta$-catenin & $97,7 \pm 8,5$ & $63,7+3,7^{*}$ \\
\hline$* \mathrm{P}<0.05, * * \mathrm{P}<0.01, * * * \mathrm{P}<0.001$. &
\end{tabular}

Actin is the basis of microfilaments, which penetrating the cytoplasm of cells and serve as a reference skeleton. It was established the high level of actin expression 
in adipose derived mesenchymal stem cells at the $\mathrm{IV}^{\text {th }}$ passage and presence a large number of actin-positive cells at the $\mathrm{X}^{\text {th }}$ passage. Although actin expression at the $\mathrm{X}^{\text {th }}$ passage is significantly reduced by $13 \%$ compared with its expression at the $I^{\text {th }}$ passage, with each subsequent number of passages the number of actin-positive cells remains high, that confirms the preservation of motor and contractile function of cells at a high level (Fig. 2).

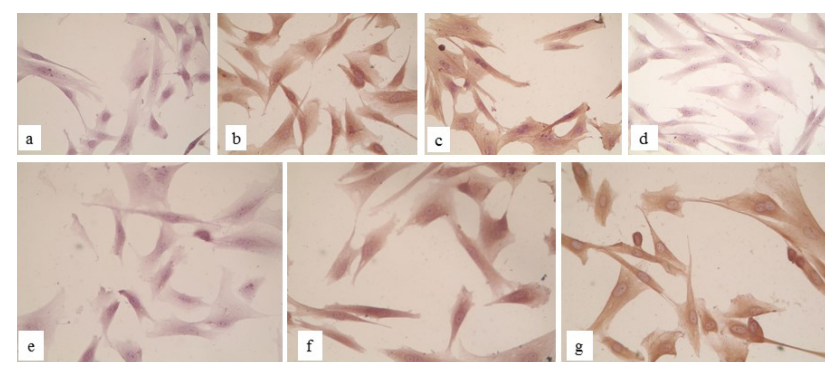

Fig. 2. Immunophenotypic characterisation of dog adipose derived mesenchymal stem cells: a) control; b) E-cadherinpositive cells; c) actin-positive cells; d) N-cadherinnegative cells; e) CD44; f) Pan cytokeratin; g) Vimentinpositive cells $\mathrm{x} 400$.

E-cadherin belongs to the family of transmembrane glycoprotein that provide calcium-dependent cell connections in the tissues. It was found that the expression of E-cadherin at the $\mathrm{IV}^{\text {th }}$ passage was $298,3 \pm 0,97$ points and at the $\mathrm{X}^{\text {th }}$ passage was remains at a high level$223 \pm 15,68 * *(\mathrm{P}<0.01)$, confirming the sustainability of transmembrane links between cells in culture (Fig. 2). Attaching of the cytoplasmic domain of E-cadherin to the actin cytoskeleton of the cell performed by protein $\beta$-catenin through protein A-catenin. $\beta$-catenin in addition to cell adhesive function performs a signaling function in cells and involved in the processes of cell proliferation, differentiation, cell migration, and is a key protein of Wnt-signaling pathway-a chain of signaling mechanisms, consisting of Wnt ligand interactions. As for the index of $\beta$-catenin expression, its value was significantly reduced by $35 \%$ at the $\mathrm{X}^{\text {th }}$ passage in relation to the $\mathrm{IV}^{\text {th }}$ passage.

We found a considerable number of positive cells with high activity of Pan cytokeratin expression at the IV ${ }^{\text {th }}$ passage $-299 \pm 0,6$ points and increase in its activity at the $\mathrm{X}^{\text {th }}$ passage $-109 \pm 9,3 * * *$ passage, indicating that the cells had epitelial origin.

CD44 is involved in the processes of cell migration and intercellular interactions. Expression of CD44 in cells characterized by low index and, as we can see in Table I, a number of CD44-positive cells is significantly reduced at the $\mathrm{X}^{\text {th }}$ passage by $42 \%$ compared to the $\mathrm{IV}^{\text {th }}$ passage. Lack of expression of $\mathrm{N}$-cadherin on DADSCs confirms the nature of their origion, as this protein is a marker of neural stem cells. To determine the cause-effect relationships between expression level of nuclear and cytoplasmic proteins and number of passages analysis of variance was conducted (Table II). As can be seen from Table II, indicators of analysis of variance confirm a strong significant effect the number of passages on immunophenotype of stem cells from fat tissue of the dog $(r=-0,95-0,27 ; p<0,05-0,001)$.

Apparently these changes in cells immunophenotype associated with repeated exposure to chemical and physical factors and biological age-related changes in cells.

Table II. The impact the number of passages (IV th and $\mathrm{X}^{\text {th }}$ ) on immunophenotype of dogs adipose-derivated stem cells $\left(\eta^{2} ; n=3\right)$.

\begin{tabular}{ll}
\hline Antigen & The impact, $\mathbf{~}^{\mathbf{2}}$ \\
\hline Vimentin & $0,73^{*}$ \\
Actin & $0,79 *$ \\
E-cadherin & $0,87 * *$ \\
N-cadherin & 0 \\
CD44 & $0,74 *$ \\
Pan cytokeratin & $0,99 * * *$ \\
$\beta$-catenin & $0,70^{*}$ \\
\hline$* \mathrm{P}<0.05, * * \mathrm{P}<0.01, * * * \mathrm{P}<0.001$.
\end{tabular}

\section{The evaluation the index of proliferation of DADSCS}

The evaluation of cell proliferation is an essential tool for exploration of cellular growth. Was established the effect of number of passages of stem cells from adipose tissue of dogs on the proliferation index (PI). The results showed, that IP was significantly greater in cells at the $\mathrm{IV}^{\text {th }}$ passage compared to cells at the $\mathrm{X}^{\text {th }}$ passage. Thus, proliferation index in cell culture at the $\mathrm{IV}^{\text {th }}$ passage was $1.90 \pm 0.02$, while at the $\mathrm{X}^{\text {th }}$ passage $-1,52 \pm 0,04 * *(\mathrm{P}$ $<0.01)$. Proliferation index decreases with the number of passages due to the biological senescence of the cells, and due to the influence on cells of chemicals and cultivation conditions. Furthermore, the decreasing of proliferation index at the $\mathrm{X}^{\text {th }}$ passage acompained with decreasing of expression of cytoplasmic and membrane proteins, which are associated with proliferation of cells. Performed variance analysis showed that passaging of cells affects on proliferation index with a force of $\eta^{2}=0.94 * *$.

\section{DISCUSSION}

There are still questions about origin and multipotentiality of MSCs. MSCs can be considered 
nonhemopoietic multipotent stem-like cells that are capable of differentiating into both mesenchymal and nonmesenchymal lineages (Giordano et al., 2007). However, there is no specific single marker to clearly define MSCs. In fact, at present, MSCs are identified through a combination of physical, phenotypic, and functional properties. The classical assay used to identify MSCs is the colony forming unit assay that identifies adherent spindle shaped cells that proliferate to form colonies and can be induced to differentiate into adipocytes, osteocytes, and chondrocytes. Furthermore, it is still questionable whether MSCs from bone marrow differentiate into keratinocytes in normal wound repair, in contrast to MSCs from adipose tissue (Sasaki et al., 2008; Giordano et al., 2007).

Adipose tissue for obtain stem cells were taken from the dogs under 1 year old. This is due to the fact that age-related changes in the body exert effects on tissues, including fat, which in turn causes the less active output stem cells from tissue in processes cultivation. This is consistent with current data research (Astor et al., 2013). We received during culturing dogs adipose-derivated stem cells were fibroblast morphology as the IVth and the Xth passage. Proliferation index was on a high level as the $\mathrm{IV}^{\text {th }}$ and the $\mathrm{X}^{\text {th }}$ passage, but at the same time it decreases with the number of passages due to the biological senescence of the cells, and due to the influence on cells of chemicals and cultivation conditions. Our findings are in agreement with the results obtained by other researchers (Neupane et al., 2008). During the immunophenotypic characterisation of equine bone marrow multipotent stem cells was recorded significantly lower expression of Vimentin, Actin, E-cadherin, CD44 on II nd passage, wich certifying the low activity of cells. Moreover it was recorded the expression of $\mathrm{N}$-cadherin, which is a marker of neural cells (Mazurkevych et al., 2016). This confirms that bone marrow-derived mesenchymal stem cells change phenotype following in vitro culture (Chamberlain et al., 2007; Bara et al., 2014). This coincides with the results of our research.

As a result, stem cells from dogs adipose tissue for $\mathrm{IV}^{\text {th }}$ and the $X^{\text {th }}$ passages culture characterized by the expression of cytoplasmic and membrane markers characterizing active proliferation, adhesion and movement properties. As the number of passages the expression of markers was significantly reduced. Index proliferation of adiposederivated stem cells significantly reduced the number of passages that certifies the change immunophenotype of these cells.

\section{CONCLUSIONS}

Adipose tissue of dogs contains multipotent stem cells that are characterized by the expression of cytoplasmic and membrane proteins, which are specific to proliferating cells.

Adipose derived mesenchymal stem cells of dogs at the $\mathrm{IV}^{\text {th }}$ passage are characterized by a maximum level of expression of pan cytokeratin $-299+0,6$, actin $-299 \pm$ 0,58, vimentin $-265,7 \pm 20,7$, E-cadherin $-298,3 \pm 1$ and no low level of $\beta$-catenin $-97,7 \pm 8,5, \mathrm{CD} 44-26,3 \pm$ 3,1 points, It indicated that this cells have a high adhesive properties, proliferation activity, cell signaling, interaction and mobility. The level of expression of these proteins remains high in the culture of stem cells also at the $\mathrm{X}^{\text {th }}$ passage, although it is significantly lower in relation to the IV passage. Adipose derived mesenchymal stem cells of dogs does not express of $\mathrm{N}$-cadherin. The result of variance analysis revealed a significant effect of cell passaging on the level of expression of cytoplasmic and membrane proteins. Proliferation index of stem cells from adipose tissue of dogs is significantly greater in cells at the $\mathrm{IV}^{\text {th }}$ passage compared to cells at the $\mathrm{X}^{\text {th }}$.

\section{Statement of conflict of interest}

The authors declares that there is no conflict of interests regarding the publication of this article.

\section{REFERENCES}

Andraszek, K., Gryzinska, M., Danielewicz, A., Batkowska, J. and Smalec, E., 2016. Agedependent stability of nucleoli and global DNA methylation level in spermatocytes of the domestic horse (Equus caballus). Can. J. Anim. Sci., 96: 215220. https://doi.org/10.1139/cjas-2015-0076

Andraszek, K., Gryzińska, M., Knaga, S., Wójcik, E. and Smalec, E., 2012. Number and size of nucleoli in the spermatocytes of chicken and Japanese quail. Folia Biol. Krakow, 60: 121-127. https://doi. org/10.3409/fb60_3-4.121-127

Astor, D.E., Hoelzler, M.G., Harman, R. and Bastian, R.P., 2013. Patient factors influencing the concentration of stromal vascular fraction (SVF) for adipose-derived stromal cell (ASC) therapy in dogs. Can. J. Vet. Res., 77: 177-182.

Azam, A., Asma-Ul-Husna, Qadeer, S., Shahzad, Q., Ejaz, R., Ullah, N., Akhtar, T., Shamim Akhter S., 2019. Synthetic oviductal fluid medium with isologous oviductal epithelial cells improves the development of in vitro produced Nili Ravi Buffalo (Bubalus bubalis) embryos. Pakistan J. Zool., 51: 2007-2014.

Bara, J.J., Richards, R.G., Alini, M., Stoddart, M.J., 2014. Concise review: Bone marrow-derived 
mesenchymal stem cells change phenotype following in vitro culture: implications for basic research and the clinic. Stem Cells, 32: 1713-1723. https://doi.org/10.1002/stem.1649

Bunnell, B.A., Flaat, M., Gagliardi, C., Patel, B. and Ripoll, C., 2008. Adipose-derived stem cells: isolation, expansion and differentiation. Methods, 45: 115-120. https://doi.org/10.1016/j. ymeth.2008.03.006

Cao, H., Heazlewood, S., Williams, B., Cardozo, D., Nigro, J., Oteiza, A., Nilsson, S., 2016. The role of CD44 in fetal and adult hematopoietic stem cell regulation. Haematologica, 101: 26-37. https://doi. org/10.3324/haematol.2015.135921

Chalasani, K. and Brewster, R.M., 2011. N-cadherinmediated cell adhesion restricts cell proliferation in the dorsal neural tube. Mol. Biol. Cell, 22: 15051515. https://doi.org/10.1091/mbc.e10-08-0675

Chamberlain, G., Fox, J., Ashton, B. and Middleton, J., 2007. Concise review: mesenchymal stem cells: their phenotype, differentiation capacity, immunological features, and potential for homing. Stem Cells, 25: 2739-2749. https://doi.org/10.1634/ stemcells.2007-0197

Chen, D., Zhong, W., Luo, L., Huang, X., Qian, W., Wang, H., Li, S. and Liu, J., 2015. E-cadherin maintains the activity of neural stem cells and inhibits the migration. Int. J. clin. exp. Pathol., 8: 14247-14251.

Chomik, P., Gryzinska, M., Batkowska, J., JezewskaWitkowska, G. and Kocki, J., 2016. Impact of lymphocyte culture media on the number of metaphases and chromosome band resolution. Post. Hig. Med. Dosw., 70: 1095-1100. https://doi. org/10.5604/17322693.1221785

Detre, S., Saclani, Jotti G. and Dowsett, M., 1995. A "quickscore" method for immunohistochemical semiquantitation: validation for oestrogen receptor in breast carcinomas. J. clin. Pathol., 48: 876-878. https://doi.org/10.1136/jcp.48.9.876

Giordano, A., Galderisi, U. and Marino, I.R., 2007. From the laboratory bench to the patient's bedside: an update on clinical trials with mesenchymal stem cells. J. Cell. Physiol., 211: 27-35. https://doi. org/10.1002/jcp.20959

Gluzman, D.F., Abramenko, I.V., Sklyarenko, L.M., Kryachok, I.A. and Nadgornaya, V.A., 2000. Leukemia diagnosis. Atlas and practical manual. Morion, Kyiv, 1-224.

Jamali, N.U., Kaka, A., Khatri, P., Malhi, M., Naeem, M., Memon, A.A., Kaleri, R.R. Janyaro, H. and Kalhoro D.H., 2019. Effect of in vitro selenium addition to the semen extender on the spermatozoa characteristics before and after freezing in Kundhi buffalo bull and in vivo fertility rate. Pakistan J. Zool., 51: 317-323.

Kladnytska, L.V., Nikulina, V.V., Garmanchuk, L.V., Mazurkevych, A.Y., Kovpak, V.V., Nikolaienko, T.V., Shelest, D.V., Dzhus, O.I., Skachkova, O.V., Stupak, Y.A. and Dasyukevich, O.I., 2014. Influence allogeneic mesenchymal stem cells on the tumour growth parameters and metastatic potential in the transplantable carcinoma lung Lewis. J. Anim. Vet. Sci., 1: 1-5.

Kladnytska, L.V, Mazurkevych, A.J, Velychko, S.V. and Zhigunov, O.V., 2016. To obtain stem cells from the adipose tissue of the dog. Bull. Sumy NAU, Ser. Vet., 6: 19-24.

Konze, S.A., van Diepen, L., Schröder, A., Olmer, R., Möller, H., Pich, A., Weißmann, R., Kuss, A.W., Zweigerdt, R. and Buettner, F.F., 2014. Cleavage of E-cadherin and $\beta$-catenin by calpain affects wnt signaling and spheroid formation in suspension cultures of human pluripotent stem cells. Mol. Cell Proteom., 3: 990-1007. https://doi.org/10.1074/ mcp.M113.033423

Lee, E., Park, S., Kang, S., Kim, Gi-H., Kang, H., Lee Sae, W. and Jeon, H., 2012. Spherical bullet formation via E-cadherin promotes therapeutic potency of mesenchymal stem cells derived from human umbilical cord blood for myocardial infarction. Mol. Ther., 20: 1424-1433. https://doi. org $/ 10.1038 / \mathrm{mt} .2012 .58$

Li, L., Bennett, S. and Wang, L., 2012. Role of E-cadherin and other cell adhesion molecules in survival and differentiation of human pluripotent stem cells. Cell. Adh. Migr., 1: 59-70. https://doi. org/10.4161/cam.19583

Mazurkevych, A., Malyuk, M., Bezdieniezhnykh, N., Starodub, L., Kharkevych, Y., Brusko, E., Gryzinska, M. and Jakubczak, A., 2016. Immunophenotypic characterisation and cytogenetic analysis of mesenchymal stem cells from equine bone marrow and foal umbilical cords during in vitro culture. J. Vet. Res., 60: 339-347. https://doi.org/10.1515/ jvetres-2016-0051

National Research Council, 1996. Guide for the care and use of laboratory animals. 7th edn. Washington, National Academy Press.

Neupane, M., Chang, C.C., Kiupel, M. and YuzbasiyanGurkan, V., 2008. Isolation and characterization of canine adipose-derived mesenchymal stem cells. Tissue Eng. Part A., 14: 1007-1015. https://doi. org/10.1089/ten.tea.2007.0207 
Okumura, N., Akutsu, H., Sugawara, T., Miura, T., Takezawa, Y., Hosoda, A., Yoshida, K., Ichida, J. K., Yamada, M., Hamatani, T., Kuji, N., Miyado, K., Yoshimura, Y. and Umezawa, A., 2013. $\beta$-Catenin functions pleiotropically in differentiation and tumorigenesis in mouse embryo-derived stem cells. PLoS One, 8: e63265. https://doi.org/10.1371/ journal.pone.0063265

Qian, H., Le Blanc, K. and Sigvardsson, M., 2012. Primary mesenchymal stem and progenitor cells from bone marrow lack expression of CD44 protein. J. biol. Chem., 287: 25795-25807. https:// doi.org/10.1074/jbc.M112.339622

Sasaki, M., Abe, R., Fujita, Y., Ando, S., Inokuma, D. and Shimizu, H., 2008. Mesenchymal stem cells are recruited into wounded skin and contribute to wound repair by transdifferentiation into multiple skin cell type. J. Immunol., 180: 2581-2587. https:// doi.org/10.4049/jimmunol.180.4.2581
Stefan, A. and Wenisch, S., 2015. Adipose tissue derived mesenchymal stem cells for musculoskeletal repair in veterinary medicine. Am. J. Stem Cells, 4: 1-12.

Yu, Y.T., Chien, S.C., Chen, I.Y., Lai, C.T., Tsay, Y.G., Chang, S.C. and Chang, M.F., 2016. Surface vimentin is critical for the cell entry of SARS-CoV. J. Biomed. Sci., 23: 14. https://doi.org/10.1186/ s12929-016-0234-7

Zhang, P., Chang, W., Fong, B., Gao, F., Liu, C., Alam, D., Bellusci, S. and Lu, W., 2014. Regulation of induced pluripotent stem (iPS) cell induction by Wnt/B-Catenin signaling. J. biol. Chem., 289: 9221 9232. https://doi.org/10.1074/jbc.M113.542845

Zuk, P.A., Zhu, M., Mizuno, H., Huang, J., Futrell, J.W., Katz, A.J., Benhaim, P., Lorenz, H.P. and Hedrick, M.H., 2001. Multilineage cells from human adipose tissue: implications for cell-based therapies. Tissue Eng., 7: 211-228. https://doi. org/10.1089/107632701300062859 